\title{
Methodological Proposal of Profit Distribution among the Participants of Integrated Transport System
}

\author{
Martina Gogolova \\ Department of Economics, Faculty of Operation and Economics of Transport and Communications, University of Zilina, Slovakia
}

Copyright $(2017$ by authors, all rights reserved. Authors agree that this article remains permanently open access under the terms of the Creative Commons Attribution License 4.0 International License

\begin{abstract}
This article deals with the profit distribution among public passenger transport companies - Integrated Transport System (ITS) operators in the context of the Slovak Republic. Currently, there are various problems concerning the operation of the fully and systematic regional integrated public transport in the Slovak Republic. For a correct profit distribution, it is necessary to conduct a survey dealing with the use of the ITS tickets, especially of railway tickets. This article also presents the survey results. The methodological proposal for the profit distribution is presented as a sequence of steps by means of algorithm.
\end{abstract}

Keywords Integrated Transport System, Public Passenger Transport, Profit Distribution, Research, Flow Diagram

JEL Classification: R4

\section{Introduction}

According to Poliakova [11] and Kendra [4], the Integrated Transport System (ITS) is one of the ways how to better exploit public passenger transport (PPT) in the cities and regions and at the same time to make it more attractive for its users. The aim of its creation in the given territory is according to Gregova and Dengova [3] and Tibaut et al. [12] the need to change the existing way of PPT in such a way as to be more attractive for the users and simultaneously to be economical. There is another problem where the general public transport, especially in regional or local context does not run on a profitable background. Empirical studies have pointed to the various factors which affect the revenue and profit from the public transport.

These needs generally come into existence in the situation when:

- Eliasson and Proost [2] argue that the increase of individual automobile transport (IAT) causes problems in the capacity of the on-road communications and in the impacts of this transport on life in the cities, regions and on the environment.

- $\quad$ Limited financial sources for PPT, on the one hand, and requirements of the citizens for the scope and prices of the services that are provided, on the other hand, lead to the need of a better exploitation of the transport potential that operates within a given territory.

Poliakova [11], Nedeliakova and Nedeliak [9] and Kendra [4] define the ITS as a complex, organised transport system whose basis is a co-operation of the particular subjects operating in the area of public passenger transport with the aim of ensuring transport maintenance of the region's territory by perpetually sustainable means. The function of the ITS in bigger city agglomerations is the creation of such a system, which at the point of the given economic possibilities satisfies transportation needs of the citizens and visitors of a given region by optimal means. Nadanyiova [8] and Paliderova [10] suggest that this system will provide sufficient quality and according to Krizanova and Majerova [6] also price accessible offer to potential customers. Generally, it means the use of common travel document (through tickets) regardless of the specific transport operator and mutual time and space coordination of the means of transport of the particular types of transport participating in ITS. The crucial criterion should be the accessibility of particular destinations by the most effective means. In several European countries it has been seen that after the simplification of the transport, and after the introduction of the common fare and the creation of the ITS, the amount of PPT users started to gradually increase again.

Majercak and Majercakova [7] observe that the result of the introduction of the ITS is the reduction of the proportion of cars within the overall transport extent, which results into:

- the reduction of air contamination by air pollutants,

- the reduction of noise,

- the reduction of scope of public place,

- the reduction of the costs for building infrastructure for automobiles,

- the increase of the safety,

- the increase of the general comfort of citizens. 
On the basis of the enhancement of the public passenger transport there has been a partial integration in three regions of the Slovak Republic: in Bratislava, in Kosice and in Zilina. In the Bratislava region one direction has just been integrated and this system has its own founder - "Bratislavska Integrovana doprava" (BID). In Zilina there also exists a partial integration, but only between city public transport company of Zilina (DPMZ) and the Slovak railway company (ZSSK). This system has just tariff integration without an official integrator. In the Kosice region, there exists a regional organizer (KORID) but at present, the integration is in the process of planning.

The ITS in the Slovak Republic is a system based on a free association of the ordering parties of PPT, where the organiser ensures the preparation of the order of transport outputs with the transport providers for dotation payers. The ordering parties of PPT are:

1) The city - it covers the whole transport services of the urban mass transportation (UMT), the source is a city's budget.

2) The self-governing region - it covers the grants for the basic transport services, the source is a region's budget.

3) Municipalities - they cover dotation for the remaining transport services, the source is a municipality's budget.

\section{Problems in Slovakia with Regards to the Addressed Issues}

There is an incompatibility of the ITS information system in Slovakia, the reluctance of the transport providers to cooperate and various level of responsibility for transport services at the level of towns and regions. Other aspects include the intricacy and partial injustice of the present-day manner of the profit distribution among the transport providers within the ITS. Consequently, the following methodology of the profit distribution is proposed.

In comparison with the ITS abroad there are several problems in Slovakia which can cause problems in profit distribution. In Germany and in Austria there are public transport companies that deal with the organisation of the integrated public transport, in the Czech Republic the organisation of integrated public transport falls within the competence of regional public transport organisers. The main problem from the perspective of responsibility lies in the fact that railway transport is in the competence of state (Ministry of Transport which provides the rail licences) and the regional bus transport is in the competence of self-governing regions. This is the main problem which has resulted into the fact that until now, there has not been a fully regional integrated public transport in Slovakia. Another problem lies in technical non - compatibility of fare, information and the ticketing systems of various PT operators.

Therefore, the goal of this paper is to propose a new methodology of the profit distribution of the public transport companies in the conditions of the Slovak Republic. There is an assumption that if the integration takes place at present, the proposed methodology is suitable and can be verified in the current conditions.

\section{The Distribution of the Territory into Economic Units}

For the purposes of the profit distribution it is essential to divide the territory into economic units (regions). These regions can take the form of areas or zones. The division of the territory into economic units is important especially from the perspective of the profit distribution and the dotation flow. The territory of the individual economic units in the Slovak Republic should be based on the solution in terms of transport.

Firstly, it is essential to separate profits:

1) From UMT- dotation from the city's budget.

2) From regional transport- state, region and municipalities dotation.

\section{Advantages and Disadvantages of the Territory Division into Areas and Zones}

Areas (e.g. Prague integrated transport):

- $\quad$ suitable for the regions with a strong centre and with a minimal tangential attendance,

- more unjust tariff - tangential vs. radial,

- costlier system for the founders,

- problematic determination of fare,

- more transparent for passengers.

Zones (e.g. the Integrated Transport System of South Moravian region):

- is suitable for the regions with more centres, similarly for a region with one big centre and other centres,

- there is a fairer tariff,

- less costs for the founders,

- the amount of fare is easier to determine,

- at the beginning, the system is less clear for the passengers.

On the basis of the above mentioned facts, the most suitable option for the integrated transport systems in Slovakia is the division of the territory into economic units that consist of the groups of tariff zones. Therefore, I propose to implement the following methodology of the profit distribution in the Slovak Republic, which is being used in the Integrated Transport System of South Moravian region [5] and is adjusted for the conditions of the ITS in the Slovak Republic.

\section{The Proposal of the Profit Distribution Methodology}

Until now, there have been several existing methods for 
the profit distribution. The first one is based on the fact that we do not know the passengers who are using the regional PT and therefore, sample survey is employed. Based on this survey, there is a proposal for the proportion of each PT company and its service with a proportional amount of passengers.

The second, more efficient method is based on the assumption that we know the routes of passenger, the origin and destination and the usage of service of particular public transport provider. Based on this fact, the fair profit distribution is possible. But the essential condition is that this system features the united fare and information system based on the electronic ticket (mostly contactless card). Also, the economic method that describes the various approaches has been published in various studies (e.g. in Borndörfer et al. [1]). The methodology has taken into account the fact that up to this point there has not been the same fare and the IT in bus transport and in public rail transport.

\section{Traditional Method Based on Sampling}

For the profit distribution, the PPT companies participants in the ITS in Slovakia will be divided into two groups with regards to different means of integration:

1) The PPT companies whose lines will be a part of the ITS and hence it will be possible to travel only with the ITS travel documents. With these transport providers, the profit distribution according to the outputs in the given zone will be possible.

2) The PPT companies, which will not have integrated the whole routes and which, in addition to their own travel documents issue the travel documents of the ITS.

The delimited area and the proposal of the transport solution will be chosen in such a way that the whole lines will be integrated in bus transport, in which there will be only the ITS tariff. Hence, the bus transporters should not be included in this group. At places where it should be appropriate for some chosen lines of the ITS to continue beyond the area of the ITS, two travel documents for the passengers travelling beyond the territory of the ITS will be issued - one for the section in the ITS and the other one for the section beyond the section of the ITS. The Slovak railway company (ZSSK) will be included in this group of transport providers that use their own travel documents. The profit rate will be determined on the basis of surveys of using the ITS travel documents on the trains of the Slovak railway company.

\subsection{Research into the Use of the ITS Travel Documents on the Trains of the Slovak Railway Company}

The main aim of the research will be to determine the amount and structure of the ITS travel documents being used in the integrated sections of the Slovak railway company. The results will serve as the basis in the process of the profit distribution among the companies of PPT- ITS participants in the zone more precise for the profit calculation belonging to the Slovak railway company.

An inquirer will determine the following:

- Section in which the inspection took place.

- Type of the travel document (seasonal, one - time pre-sale tickets, tickets from automatic machines).

- Within the time travel documents:

- validity of time travel documents (monthly, quarterly, yearly),

- type of time fare (of its full value, reduced),

- what zones they were bought for

- Within one-time travel documents:

- type of travel document (of its full value, reduced),

- the number of zones,

- the place of marking (bus / the platform of the Slovak railway company),

- the number of entry zone,

- route destination (see Table 1).

Table 1. The investigation of using the ITS travel documents on the Slovak railway company trains

\begin{tabular}{|c|c|c|c|c|c|c|}
\hline Section & \multicolumn{3}{|c|}{ Type of travel document } & $\begin{array}{l}\text { Number of zones } \\
\text { Number of entry zone } \\
\text { Number of zones within } \\
\text { subscription fare }\end{array}$ & $\begin{array}{l}\text { Place of } \\
\text { marking }\end{array}$ & $\begin{array}{l}\text { Route } \\
\text { destination }\end{array}$ \\
\hline \multirow{3}{*}{$\begin{array}{c}\text { e.g. } \\
\text { Zilina-Rajec }\end{array}$} & one-time, non-address & full-bodied & monthly & e.g. 6 & bus & \multirow{3}{*}{$\begin{array}{c}\text { e.g. } \\
\text { Rajecke } \\
\text { Teplice }\end{array}$} \\
\hline & one-time, address & reduced & trimestral & 2 & city buses & \\
\hline & subscription fare & & annual & 123 & train & \\
\hline
\end{tabular}


Research will take place on a selected working day and during one weekend day from 4:00 a.m. to 0:00 a.m. Wednesday will be selected as a typical working day. It is the official day when a significant amount of passengers is travelling also in the morning hours. Simultaneously, the traffic is not influenced by Monday's and Friday's citizen movement. On Tuesdays and Thursdays, the amount of transported passengers is lower. On weekends, the research will take place on Saturday. In co-operation with the Slovak railway company, the inquirers will be accompanying the train conductors on trains during their inspection. The train conductor will be instructed to do the inspection actively during the whole period of train journey and will also be instructed to check each passenger.

Research will be conducted in such a way that all the passengers in all of the Slovak trains in the ITS will be given questions. Within the frequently more loaded trains, the research will include more inquirers who will move ahead from both tails of the train set. In case that not all of the passengers on the train are questioned, the inquirer will note this fact into the form. The inquirer will provide the number of carriages in which $\mathrm{s} / \mathrm{he}$ was not able to carry out the research.

The overall number of the passengers travelling with the ITS travel documents will be determined by the ratio of the overall number of the carriages to the number of carriages in which the research was carried out. With trains on which it will not be possible to carry out the research due to technical reasons, the research procedure will be repeated. Taking into account that individual sections of the railways pass through or are ending in cities, there will not be a need to conduct a special research within those territories.

The evaluation of the research will be composed of three steps:

1) Step: redistribution of profit into individual zones (profit only from the fare, where passengers used the railway).

2) Step: ratio of profit within the zones belonging to the Slovak railway company.

3) Step: profit ratio index belonging to the railway.

\subsection{Profit Ratio in Economical Units Belonging to the Slovak Railway Company}

\subsubsection{Profit from One-Time Travel Documents}

In a given zone, a part of the price of travel document belongs to the Slovak railway company and will be determined from the following pattern:

$$
C_{J C}=C_{J(\text { zoneA })} \cdot k_{k}
$$

Where:

- $\mathrm{C}_{\mathrm{J}(\mathrm{zone} \text { A) }}$ is part of the price of travel document allotted to a given zone.

- $\quad \mathrm{k}_{\mathrm{k}}$ the combination coefficient of train, bus, and UMT. Possible values of this coefficient will be determined according to travel means in a given zone.

\subsubsection{Profit from the Pre-Paid Fare}

In a given zone, a part of the price of travel document belongs to the Slovak railway company and will be determined from the following formula:

$$
C_{P C}=\frac{C_{J(\text { zone }) ~} \cdot k_{k}}{2}
$$

Where:

- $\mathrm{C}_{\mathrm{J} \text { (the } \mathrm{A} \text { zone) }}$ is a part of the price of travel document allotted to a given economic unit.

- $\mathrm{k}_{\mathrm{k}}$ is the combination coefficient of index train, bus, UMT. Possible values of this coefficient will be determined according to travel means in a given zone.

It is assumed that every passenger with time travel document makes two routes per day by the same means. Consequently, this causes the fact that within the adding in the trains each owner of subscription fare will be counted at least two times. That is why the amount of fare belonging to the Slovak railway company in a given zone is divided by two. The profit in a given economic unit belonging to the Slovak railway company will be calculated as a sum of profit from individual travel documents.

\subsubsection{Profit Distribution among the PPT Companies (not Including the Slovak Railway Company) inside the Zone}

Profit among the PPT companies inside the zone will be distributed on the basis of a number of vehicle kilometres travelled with the respect to the capacity of individual means of transport types. Each provider of transport will receive a share from the revenue in a given zone after the profit subtraction for the Slovak railway company on the basis of the following formula:

$$
T_{D}=\frac{\sum k_{O B} \cdot v_{D k m}}{\sum k_{O B} \cdot v_{k m}} \cdot T_{z o n e A}
$$

Where:

- $\quad \mathrm{V}_{\mathrm{km}}$ is the number of vehicle kilometres travelled by a given type of a vehicle in a given zone.

- $\mathrm{V}_{\mathrm{Dkm}}$ is the number of vehicle kilometres travelled by a given transporter, by a given type of vehicle in a given zone.

- $\mathrm{T}_{\text {zone A }}$ is profit in a given zone after the subtraction of the Slovak railway company part.

- $\mathrm{k}_{\mathrm{OB}}$ is the vehicle occupancy index.

\section{Conclusions}

The profit distribution is based on the daily report of the passenger flow. The new method takes into account the following aspect - the origin and destination of passengers will be familiar from the prepaid tickets - cards. On the basis 
of this, the shortest route will be calculated, if the ID of passenger will be present in the database of PT companies, they can expect certain amount of money proportionally distributed among the companies.

The sampling method proved as the possible solutions if the data about passenger is not available. The exact method based on IT provides the real output, but as it has been mentioned above, until now this is not the case of the Slovak Republic.

The following algorithm (Figure 1) illustrates the above mentioned proposed methodology of the profit distribution among the PPT companies - the ITS participants in Slovakia.

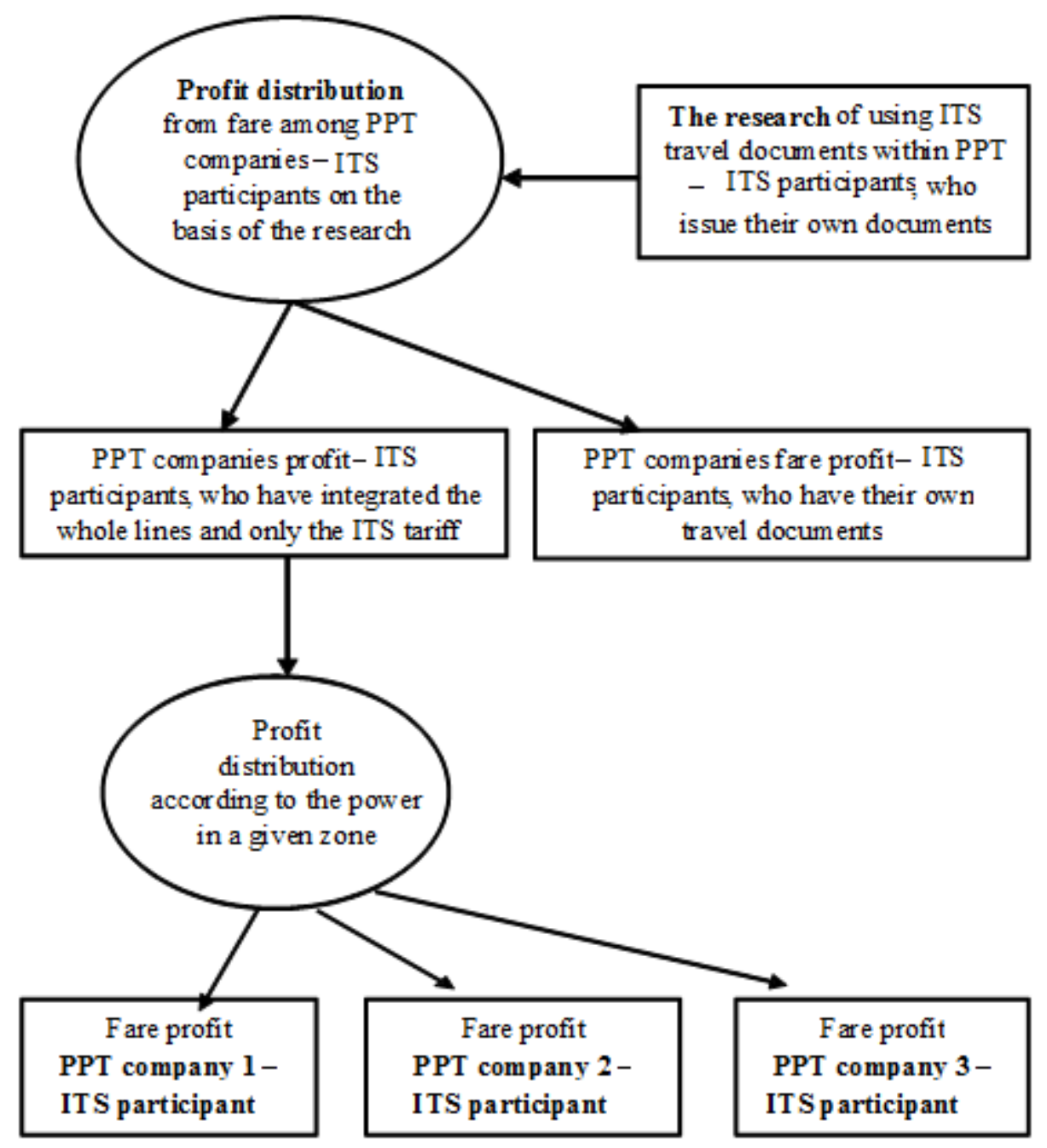

Figure 1. The algorithm of the profit distribution among PPT companies- the ITS participants inside a zone 
Legal rules and regulations of the Slovak Republic are very deficient in the area of the ITS. There is no act in the legislative of the Slovak Republic that defines either the term basic transport service of the territory or the term integrated service of the territory or the term integrated transport. It is vital to initiate the inception of a new, separated act on the ITS, which would solve this problem. Alternatively, this problem could be solved in a sufficient extent by way of adding amendments to the existing laws. The inclusion of the term integrated transport system into Slovak legislative system is an important step in the process of applying the effort of implementing the ITS in praxis. The increase of profit and revenue also rests in technological providing of services, higher frequency, and the improvement of quality.

\section{REFERENCES}

[1] Borndörfer, R., Karbstein, M., Pfetsch M. E. Models for fare planning in public transport. Discrete Applied Mathematics. Elsevier, volume 160, issue 18. December 2012, pp. 25912605

[2] Eliasson, J., Proost, S. Is sustainable transport policy sustainable? Transport Policy. Elsevier, volume 37. January 2015, pp. $92-100$

[3] Gregova, E., Dengova, E. Integrated Transport System - A Form of Improving Public Passenger Transport. In: 2nd International Conference on Social Sciences Research (SSR 2014), Advances in Social and Behavioral Sciences, Vol. 5, Hong Kong, Singapore Management and Sports Science Institute, ISSN: 2339-5133, pp. 20-25.

[4] Kendra, M. Integration of individual car transport and public passenger transport in cities. OPTi: Proceedings: 1st international conference on engineering and applied sciences optimization. 2014, ISBN 978-960-99994-6-5, pp. 1582-1592.
[5] KORDIS JMK, spol. s.r.o. Annual information. Internal materials. Brno

[6] Krizanova, A., Majerova, J. The proposal of activities of pricing policy in the process of building and managing brand value in Slovak Republic. In: International Conference on Information, Business and Education Technology (ICIBET), Advances in Intelligent Systems Research, Vol. 26, Beijing, CHINA. 2013, ISSN: 1951-6851, pp. 416-419

[7] Majercak, P., Majercakova, E. Internal Audit Compliance with Environmental Standards in Railway Company Cargo Slovakia. In: 17th International Conference on Transport Means, Transport Means - Proceedings of the International Conference, Kaunas, LITHUANIA. 2013, ISSN: 1822-296X, pp. 326-329

[8] Nadanyiova, M. The Customer Satisfaction with Services Railway Company Cargo Slovakia as a Factor of Competitiveness. 18th International Conference on Transport Means, Transport Means - Proceedings of the International Conference, Kaunas, Lithuania. 2014, ISSN: 1822-296X, pp. 120-124

[9] Nedeliakova, E., Nedeliak, I. Quality level of an integrated transport system in the context of information and communication technologies. Transport \& logistics. 2013, ISSN 1451-107X, Roč. 13, č. 28, pp. 1-8.

[10] Paliderova, M. Railway transport service quality: factor of competitiveness and profitability of the transport firm. Transport means 2014: proceedings of the 18th international conference: October 2014, Kaunas University of Technology, Lithuania. - ISSN 1822-296X. - Kaunas: Kaunas University of Technology, pp. 20-23.

[11] Poliakova, B. The planning of integrated transport system in regard to the development of the area. Logi: scientific journal on transport and logistics. 2012, ISSN 1804-3216. Vol. 3, No. 1, pp. 83-91

[12] Tibaut, A., Kaucic, B., Rebolj, D. A standardised approach for sustainable interoperability between public transport passenger information systems. Computers in Industry, Elsevier, volume 63, Issue 8. October 2012, pp. 788-798 